症例報告

\title{
緩徐な増大が疑われた multinodular and vacuolating neuronal tumor (MVNT)
}

\author{
伊藤 寛, 中原 由紀子, 若宮 富浩, 高口 素史, 吉岡 史隆, 井上 浩平, 緒方 敦之, \\ 増岡 淳, 阿部 竜也 \\ 佐賀大学医学部脳神経外科
}

\section{Multinodular and Vacuolating Neuronal Tumors with Suggested Slow Progression}

\author{
Hiroshi Ito, M.D., Yukiko Nakahara, M.D., Tomihiro Wakamiya, M.D., Motofumi Koguchi, M.D., \\ Fumitaka Yoshioka, M.D., Kohei Inoue, M.D., Atsushi Ogata, M.D., Jun Masuoka, M.D., \\ and Tatsuya Abe, M.D.
}

Department of Neurosurgery, Faculty of Medicine, Saga University

Multinodular and vacuolating neuronal tumors (MVNT) were recently included in the 2016 World Health Organization classification of central nervous system tumors. In previous case reports and published papers, MVNTs are described as benign tumors associated with epilepsy and rarely presenting with progressive features. Herein, we report three cases of resected MVNTs with slow progression. None of the patients exhibited neurological symptoms or had a history of epilepsy, and all were diagnosed incidentally using magnetic resonance imaging(MRI). In all three cases, MRI of the subcortical region revealed hypointensity on T1-weighted images (T1-WI) and hyperintensity on T2-WI and fluid-attenuated inversion recovery (FLAIR) images. The T1-WI lesions were not enhanced with gadolinium. One patient demonstrated suggested slow expansion of the lesion during the 7-year follow-up visit. As the results suggested the possibility of progressive tumors, including lower-grade gliomas, surgery was performed to obtain pathological and genetic diagnoses. Histopathological findings revealed typical features of MVNT such as multinodular lesions in the cerebral subcortex and proliferating atypical cells with vacuolating features in the tumors.

Immunohistochemical tests demonstrated that anti-synaptophysin and anti-Olig2 antibodies stained the tumor cells. DNA sequencing analysis revealed that IDH1-R132, IDH2-R172, H3F3A-K27, -G34, HIST1H3B-K27, -G34, TERT promoter-C228, -C250, and BRAF-V600 were not mutated. Additional data on characteristic features of MVNT revealed by MRI are required to determine treatment strategies for hyperintensity lesions detected on T2-WI, including lower grade gliomas.

(Received March 1, 2020; accepted April 21, 2020)

Key words : multinodular and vacuolating neuronal tumor, progression, lower grade glioma

Jpn J Neurosurg（Tokyo）29:580-585, 2020

連絡先：伊藤 寛, $\bar{\top}$ 849-8501 佐賀市鍋島 5-1-1 佐賀大学医学部脳神経外科

Address reprint requests to: Hiroshi Ito, M.D., Department of Neurosurgery, Faculty of Medicine, Saga University, 5-1-1 Nabeshima, Saga-shi, Saga 849-8501, Japan 


\section{緒 言}

Multinodular and vacuolating neuronal tumor (MVNT) は, WHO 2016 中枢神経系腫瘍分類改定で記載が追加さ れた疾患概念である ${ }^{11)}$. 通常, MRI で皮質下の多結節性 の $\mathrm{T} 2$ 高信号の病変として描出され, 造影効果はなく,

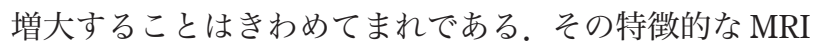
所見より MVNT と画像診断をつけることは可能である が，病変が増大する場合には低悪性度神経膠腫との鑑別 が問題となる。これまでに当院で経験した MVNT 1 例と MVNT と推定された 2 例を提示する. 特に 7 年の経過観 察の間に緩徐に増大傾向を示していると考えられた MVNT の 1 例について自然経過, 画像所見, 病理学的所 見を中心に，文献的考察を加え報告する.

\section{症例提示}

症例 1 は 35 歳女性, 症例 2 は 35 歳女性, 症例 3 は 22 歳男性で, 比較的若年層の症例である.いずれの症例も, 頭痛の精査で頭部 MRI を受け, それぞれ前頭葉皮質下白 質に病変を指摘された。画像上病変は $\mathrm{T} 2$ 強調画像で高 信号を呈し, 境界明膫な斑状な部分と, その辺緑に多結 節状の部分を伴っていた（Fig. 1)。同病変はガドリニウ ムで造影されなかった（Fig. 1)。いずれの症例も，てん かんの既往はなく, 神経学的異常所見はないことから, 画像検査による慎重な経過観察の方針とした。症例 2, 3 は画像上, MVNT と推定され，1年以上に及ぶ経過観察 で画像上の増大所見を呈さなかった。

一方, 症例 1 は 7 年間の長期的な経過で, 神経学的異 常所見やてんかん発作の出現はなかったが, 病変は緩徐 な増大が疑われた（Fig. 2A-C). MR spectroscopy (MRS) を施行したところ，n-acetyl aspartate（NAA）のピーク は軽度低下, lipid/lactate ピークは上昇なく, 低悪性度神 経膠腫や脱檤性疾患などが考えられた (Fig. 2D) 。病変 が増大傾向にあると考元られ, 画像診断上, 低悪性度神 経膠腫が否定できなかったため, 病理組織診断を得る必 要があると判断し, 開頭腫瘍摘出術を施行した。肉眼的 には，腫瘍は脳表からは観察されず（Fig. 3A），白質を 中心に結節状の病変が認められた。病変は $5-$ aminolevulinic acid (5-ALA) による蛍光は示さなかった (Fig. 3B). 術中迅速病理検査では, 明瞭な核小体を有し, 細胞質に 空胞化を伴う異型細胞を認め, 免疫組織染色では, GFAPが陰性であり，MVNTが疑われたが，可及的に摘 出を行い亜全摘で手術を終えた.

病理組織学的には, 白質に多結節状に腫瘍が進展して
おり（Fig. 3C)，空胞形成を伴う異型細胞が増殖していた (Fig. 3D-F). 免疫組織染色では, シナプトフィジン, Olig2 抗体染色が陽性（Fig. 3G，H）であり，クロモグラ ニン A, GFAP 抗体染色は陰性（Fig. 3I，J）で, Ki-67 LI は $1 \%$ 未満であった (Fig. 3K)。 サンガーシークエンス法 にて腫瘍細胞の遺伝子変異を検討したが, 神経膠腫に特 徵的な IDH1-R132,IDH2-R172, H3F3A-K27, -G34, HIST1H3B-K27, -G34, TERT promotor-C228, -C250, $B R A F-\mathrm{V} 600$ 変異はなかった. 以上の所見より, MVNT と診断した。術後, 半年以上の経過となるが, 再発は認 めていない.

\section{考 察}

MVNT は 2013 年 Huse ら ${ }^{9)}$ にって報告されたまれな 疾患であり，いまだに neoplasia か dysplasia かという点 には議論がある ${ }^{18)}$ 。これまでに渉猟し得るMVNT の経過 に関する報告は 111 例である。本症例報告も含め, 41 例 に対し外科手術が施行され病理組織診断が得られてい る1224)(6)-9) 12) 14) 17) 18)20)211. 外科手術を含め治療を行わず, 自然経過を観察した報告は 71 例である ${ }^{13) 10) 13) ， そ の 中 ~}$ で, 一過性に増大した報告が 1 例のみ ${ }^{1}$ であり, 経過観 察中に増大傾向があったとする報告はない。こうした事 実に基づいて, Nunes ら ${ }^{13)}$ は, MVNT は治療を必要とし ない新たな疾患であるとし, ‘leave me alone lesion’ と表 現して報告している。これらのことから, 本報告の症例 1 のように経時的に病変の増大が疑わ机る症例はきわめ てまれといえる。一方で, MVNT のシグナル伝達の異常 としてMAPK経路の活性化が報告されており, MVNTも neoplastic な性質を有している可能性が示唆されてい $ろ^{14)}$. MVNT の分子生物学的特性の解明には, 今後も長 期の自然経過や遺伝子異常のデー夕集積が必要であると 考えられる.

MVNT の画像上の特徴として, 皮質下白質に皮質に沿 うようなリボン状の分布を示し, 境界明瞭な T2 高信号 病変として描出される(1)313)。通常, ガドリニウムによる 造影効果は 111 例中 2 例とまれで, 圧排効果も呈さない. 最も特徵的といえる所見は命名の由来ともなっている多 結節性の形態であり, 典型的には T2 高信号を示す小結 節が集簇した所見を呈する113)13)。前述したように, 通 常, 病変は経時的に増大しないため, 本報告の症例 2,3 のように特徵的な画像所見のみで診断の推定が可能であ り, 無症状であ机ば経過観察が可能であり, 増大傾向が なければ外科的介入は不要と考えられる.

しかし，本報告の症例 1 のうにきわめてまれながら， 

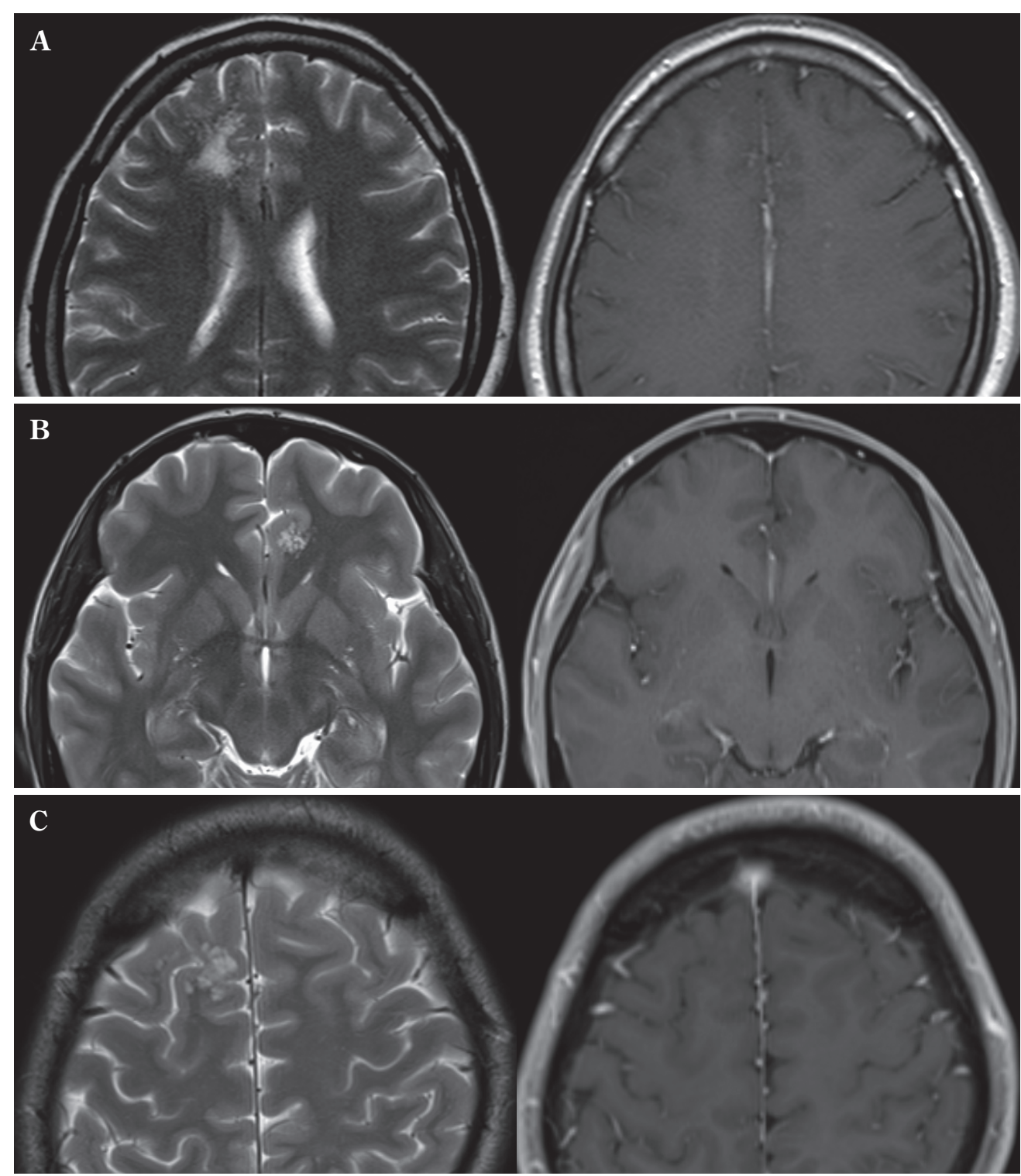

Fig. 1 Magnetic resonance imaging findings of cases 1-3

Lesions in all 3 cases reveal hyperintensity on T2-weighted images (WI), with no gadolinium enhancement on T1-WI (A, Case 1; B, Case 2 ; C, Case 3 ).

増大が疑われる症例が存在する。 その場合, 白質を主体 とした T2 高信号域を呈し，ガドリニウムによる造影効 果を有さない，増大する腫瘍との鑑別が必要であり，臨 床的に最も問題となるのは，低悪性度神経膠腫との鑑別 である。低悪性度神経膠腫は造影効果を有さない, T2 高 信号を示す malformative な腫瘍性病変，すなわち focal cortical dysplasia (FCD) や dysembryoplastic neuroepithelial tumor (DNT) といつた疾患との画像上の鑑別が議論 されてきた歴史がある16)19)。低悪性度神経膠腫と malformative な腫瘍性病変との鑑別を目的に, MRS が開発, 用 いられるようになった ${ }^{19)}$. MVNT の MRS 所見は, NAA
ピークの軽度低下, Cho/Cr 比の上昇, lipid/lactate ピー クはないか, あってもごく軽度と報告されている ${ }^{10)}$ 。し かし, 残念ながらこれらの所見は低悪性度神経膠腫の MRS 所見と同様であり，この所見のみで鑑別することは 困難である。一方で, 低悪性度神経膠腫は高頻度に $I D H 1 / 2$ の変異を有する. 変異型 $I D H 1 / 2$ はイソクエン酸 を $\alpha$-ケトグルタル酸ではなく $2-$ ヒドロキシグルタル酸 （2-HG）に代謝することが知られている。この 2-HGを MRS で検出することで IDH 変異が検出可能なことが報 告されている5)。これは, MRSを用いて $2-\mathrm{HG}$ を検出で きれば，低悪性度神経膠腫を術前に除外診断できる可能 

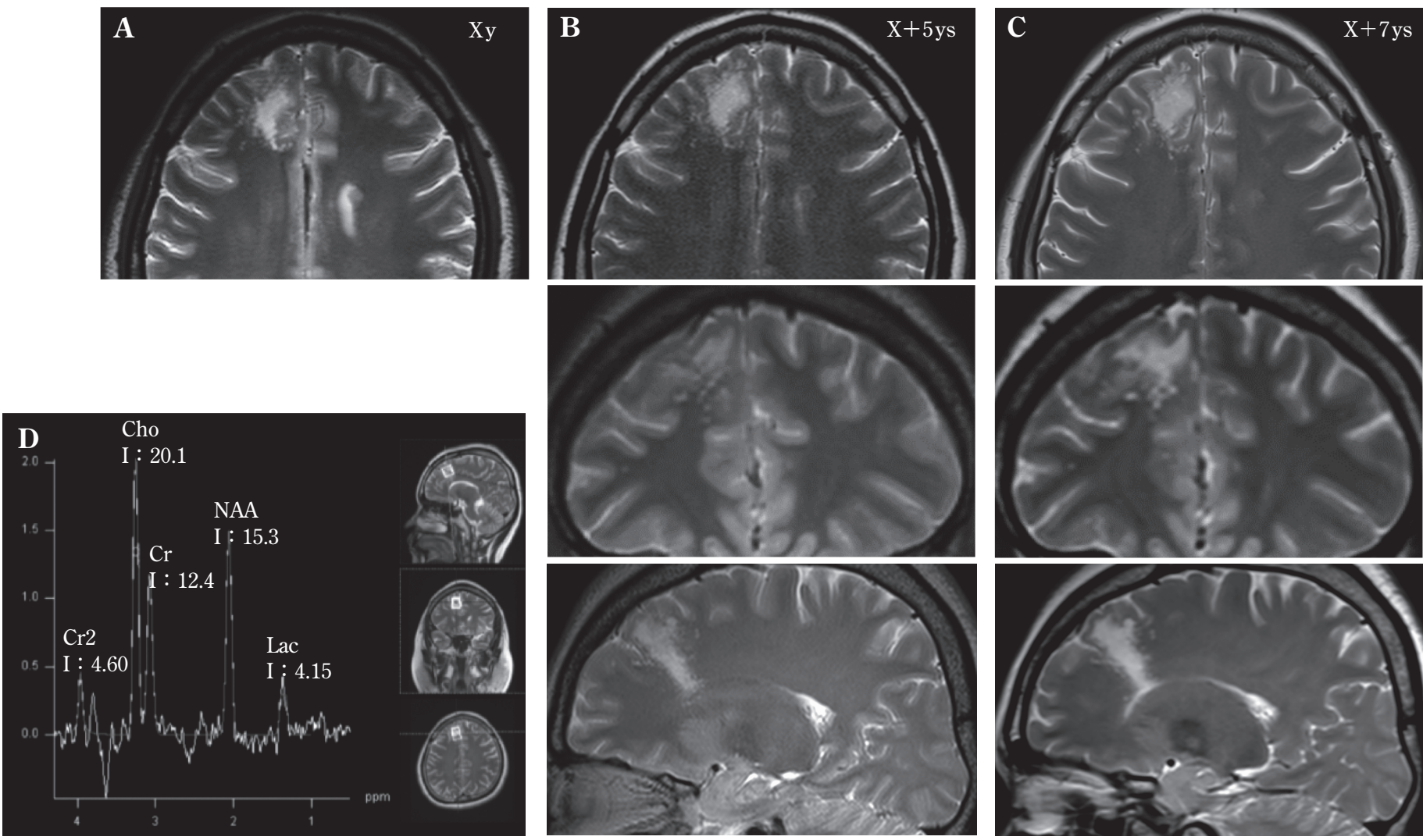

Fig. 2 Case 1 lesion showing slow progression over 7 years

Case 1 lesion exhibiting slow progression over 7 years ( $\mathbf{A}$, at diagnosis [X years] ; $\mathbf{B}$, at $\mathrm{X}+5$ years ; $\mathbf{C}$, at $\mathrm{X}+7$ years $)$ on T2weighted images of axial view (Upper), coronal view (Middle), and sagittal view (Lower). Magnetic resonance spectroscopy image revealing a mild decrease of $\mathrm{N}$-acetyl aspartate without a lipid or lactate peak, and an uptake ratio of $\mathrm{Cho} / \mathrm{Cr}(\mathbf{D})$.

性を示唆している。ただし，IDH 変異のない低悪性度神 経膠腫も存在するので，完全な術前鑑別は困難である.

また，低悪性度神経膠腫とDNTなどの malformativeな 腫瘍性病変の鑑別に $\left[{ }^{11} \mathrm{C}\right]$-methionine PET (Met-PET) の有用性が報告されている ${ }^{15)}$. Malformative な病変はメ チオニンの集積はないが，Fukushima ら゙および山澤 $ら^{21)}$ によると, MVNTもこれらの疾患と同様にメチオニ ンの集積がないとされる。これは，本報告の症例 1 のよ うに，低悪性度神経膠腫との鑑別が問題となった場合 に，Met-PETが有用である可能性を示唆している.

MVNT は病理組織学的には, 空胞化を特徵とする神経 細胞分化早期段階の異型神経細胞からなる多結節性の病 変で，皮質下白質に存在する。異型細胞では神経細胞の 分化早期段階に陽性となる $\mathrm{HuC} / \mathrm{HuD}$ が陽性であり, Olig2 が陽性であることも知られている。成熟神経細胞 のマーカーである NeuN やクロモグラニン A は陰性であ るとされている。病理学的な鑑別として神経細胞分化を 有する病変である ganglion cell tumors や DNT, malformations of cortical development (MCD) が挙げられるが, ganglion cell tumors はしばしば好酸性顆粒小体の存在や Rosenthal 線維，血管周囲リンパ球浸潤，微小石灰化の所 見を有し，これらはMVNTにはみられないと報告されて いる。 また，DNT は皮質に限局した特異グリア神経細胞 要素を有する病変であるが，MVNT には特異グリア神経 細胞要素は存在しない.MCD は異所性の成熟した皮質 であり，成熟神経細胞のマーカーである NeuN 陽性など でMVNT とは鑑別可能である. 今回問題としている低悪 性度神経膠腫とは，Olig2 陽性である点より乏突起膠腫 との鑑別が必要となるが，周囲組織への浸潤性発育の有 無や GFAP 染色や，低悪性度神経膠腫に特異的とされる 変異型 IDH1 抗体を用いた免疫染色で鑑別が可能とされ ている ${ }^{721)}$.

\section{結 語}

近年 WHO 中枢神経系腫瘍分類に加えられたまれな MVNT の症例 3 例に関して, 自然経過や画像所見につい て報告した。また，経時的な増大が疑われ外科手術を 

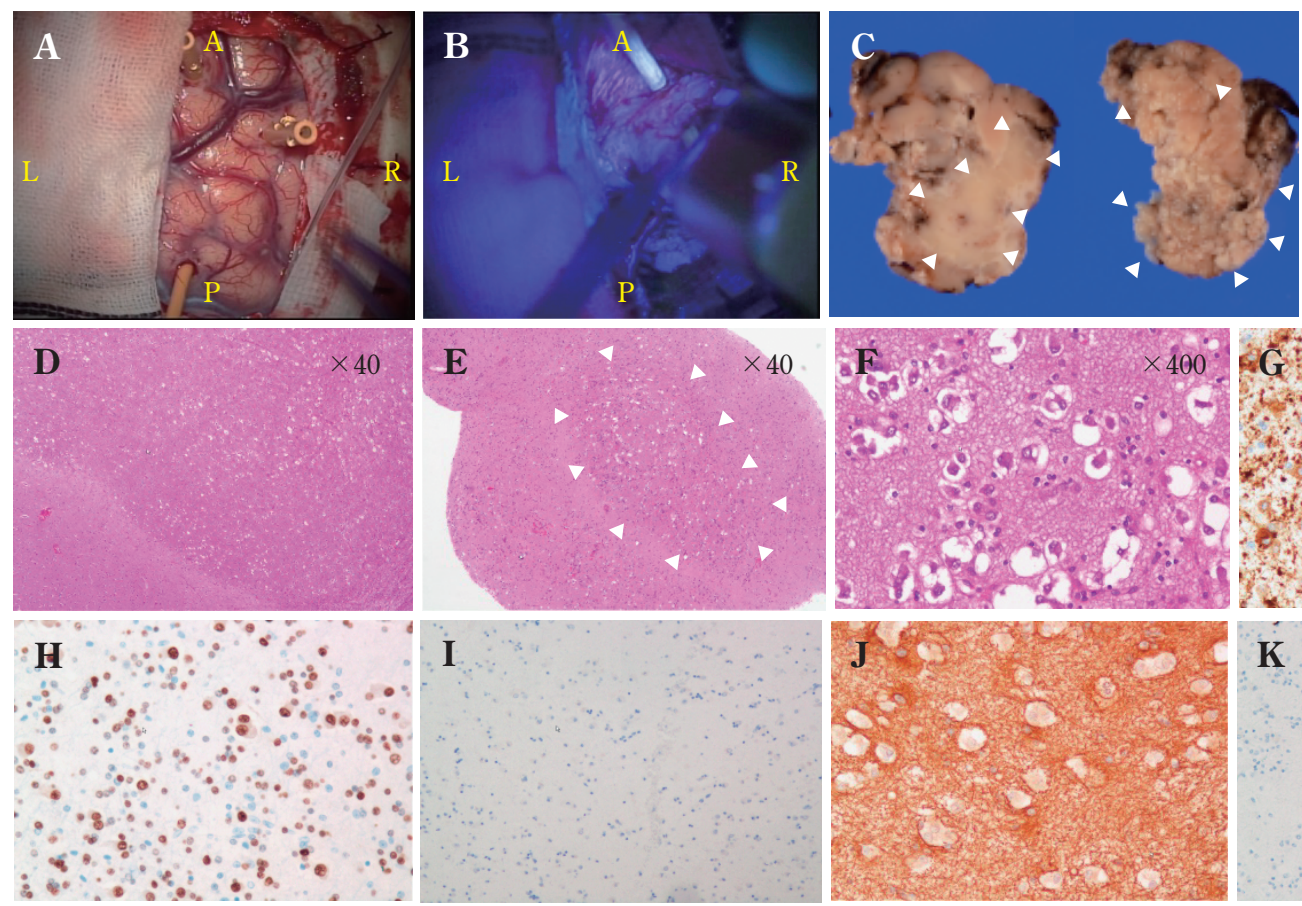

I
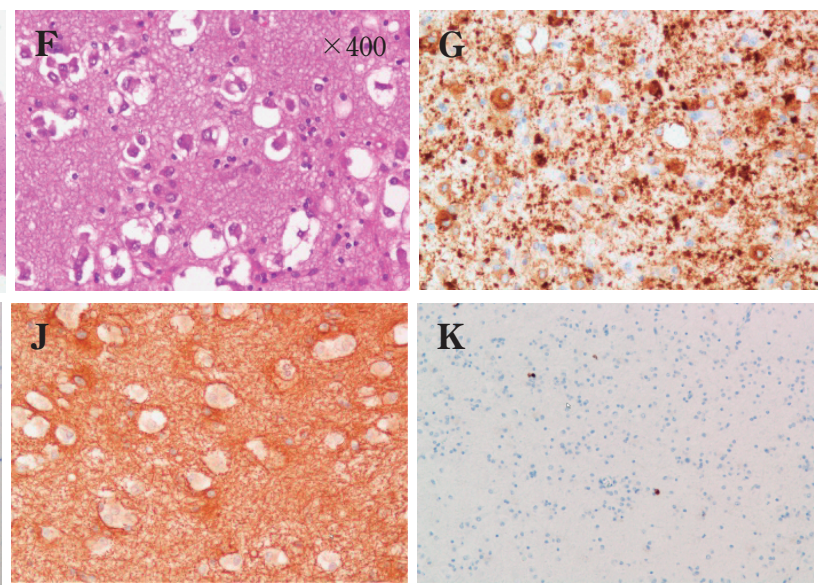

Fig. 3 Intraoperative and pathological findings of the lesion of case 1

The lesion is not observed on the surface of the cerebral cortex $(\mathbf{A})$. The lesion shows no 5-ALA-induced fluorescence (B). Typical multinodular features of the inside (Left) and outside (Right) tumor (C). Histopathological images of hematoxilin and eosin staining (D-F) : 40× magnification (D, E) ; 400 $\times$ magnification (F). Immunohistochemical analysis of the Case 1 lesion $(\mathbf{G}-\mathbf{K})$ : Synaptophysin $(\mathbf{G})$ and Olig2 (H) are positive in tumor cells ; Chromogranin A（I） and GFAP（J） are negative in tumor cells ; Ki-67 positive cell rates are less than 1\% (K).

行つた 1 例について, 手術所見, 病理組織所見, および 遺伝子解析結果について報告した。 MVNT は, MRIで特 徵的な画像所見を呈するため, 画像所見およびその後の 自然経過の観察で診断可能である。しかし，きわめてま れではあるが本報告の症例のように，緩徐な増大傾向が 疑われ，低悪性度神経膠腫との鑑別が問題となる場合が ある、そのような症例では MRSによる $2-\mathrm{HG}$ の検出や Met-PET 検査を加えることによって，より正確な術前 診断を目指す必要があると考えられた。

\section{COI}

著者全員は日本脳神経外科学会への COI 自己申告の登録を 完了しています。本論文に関して開示すべき COI はありませ h.

\section{文 献}

1) Alsufayan R, Alcaide-Leon P, de Tilly LN, Mandell DM, Krings T: Natural history of lesions with the MR imaging appearance of multinodular and vacuolating neuronal tumor. Neuroradiology 59: 873-883, 2017.

2) Bodi I, Curran O, Selway R, Elwes R, Burrone J, Laxton R, $\mathrm{Al}$-Sarraj S, Honavar M : Two cases of multinodular and vacuolating neuronal tumour. Acta Neuropathol Commun 2: 7,2014 .
3) Buffa GB, Chaves H, Serra MM, Stefanoff NI, Gagliardo AS, Yañez P: Multinodular and vacuolating neuronal tumor of the cerebrum (MVNT) : A case series and review of the literature. J Neuroradiol $\mathbf{4 7}: 216-220,2020$.

4) Cathcart SJ, Klug JR, Helvey JT, L White M, Gard AP, McComb RD: Multinodular and vacuolating neuronal tumor: A rare seizure-associated entity. Am J Surg Pathol 41: 1005-1010, 2017.

5) Choi C, Ganji SK, DeBerardinis RJ, Hatanpaa KJ, Rakheja D, Kovacs Z, Yang XL, Mashimo T, Raisanen JM, Marin-Valencia I, Pascual JM, Madden CJ, Mickey BE, Malloy CR, Bachoo RM, Maher EA : 2-hydroxyglutarate detection by magnetic resonance spectroscopy in IDH-mutated patients with gliomas. Nat Med 18:624-629, 2012.

6) Choi E, Kim SI, Won JK, Chung CK, Kim SK, Choi SH, Choi S, Han B, Ahn B, Im SW, Park SH : Clinicopathological and molecular analysis of multinodular and vacuolating neuronal tumors of the cerebrum. Hum Pathol $\quad 86:$ 203-212, 2019.

7) Fukushima S, Yoshida A, Narita Y, Arita H, Ohno M, Miyakita Y, Ichimura K, Shibui S : Multinodular and vacuolating neuronal tumor of the cerebrum. Brain Tumor Pathol 32: 131-136, 2015.

8) Gonzalez-Quarante LH, Ruiz-Juretschke F, Sola Vendrell E, Gil de Sagredo Del Corral OL, Agarwal V, Garcia-Leal R: Multinodular and vacuolating neuronal tumor of the cerebrum. A rare entity. New case and review of the literature. Neurocirugia (Astur) 29: 44-55, 2018.

9) Huse JT, Edgar M, Halliday J, Mikolaenko I, Lavi E, Rosenblum MK: Multinodular and vacuolating neuronal tumors of 
the cerebrum : 10 cases of a distinctive seizure-associated lesion. Brain Pathol 23: 515-524, 2013.

10) Lecler A, Chauvet D, Biassette HA, Savatovsky J : Multiparametric imaging improves confidence in the diagnosis of multinodular and vacuolating neuronal tumor of the cerebrum. AJNR Am J Neuroradiol 39: E32-33, 2018.

11) Louis DN, Perry A, Reifenberger G, von Deimling A, Figarella-Branger D, Cavenee WK, Ohgaki H, Wiestler OD, Kleihues P, Ellison DW : The 2016 World Health Organization classification of tumors of the central nervous system : a summary. Acta Neuropathol 131: 803-820, 2016.

12) Nagaishi M, Yokoo H, Nobusawa S, Fujii Y, Sugiura Y, Suzuki R, Tanaka Y, Suzuki K, Hyodo A : Localized overexpression of alpha-internexin within nodules in multinodular and vacuolating neuronal tumors. Neuropathology 35:561-568, 2015.

13) Nunes RH, Hsu CC, da Rocha AJ, do Amaral LLF, Godoy LFS, Watkins TW, Marussi VH, Warmuth-Metz M, Alves HC, Goncalves FG, Kleinschmidt-DeMasters BK, Osborn AG : Multinodular and Vacuolating Neuronal Tumor of the Cerebrum: A new "leave me alone" lesion with a characteristic imaging pattern. AJNR Am J Neuroradiol $\mathbf{3 8}$ : 1899-1904, 2017.

14) Pekmezci M, Stevers M, Phillips JJ, Van Ziffle J, Bastian BC, Tsankova NM, Kleinschmidt-DeMasters BK, Rosenblum MK, Tihan T, Perry A, Solomon DA : Multinodular and vacuolating neuronal tumor of the cerebrum is a clonal neoplasm defined by genetic alterations that activate the MAP kinase signaling pathway. Acta Neuropathol 135 : 485-488, 2018.

15) Rosenberg DS, Demarquay G, Jouvet A, Le Bars D, Streichenberger N, Sindou M, Kopp N, Mauguière F, Ryvlin
$\mathrm{P}:\left[{ }^{11} \mathrm{C}\right]$-methionine PET : dysembryoplastic neuroepithelial tumours compared with other epileptogenic brain neoplasms. J Neurol Neurosurg Psychiatry 76:1686-1692, 2005.

16) Sherburn EW, Bahn MM, Gokden M, Silbergeld DL, Rich $\mathrm{KM}$ : Dysembryoplastic neuroepithelial tumor and oligodendroglioma: the diagnostic value of magnetic resonance spectroscopy. Case report and review of the literature. Neurosurg Focus 4: e6, 1998.

17) Shitara S, Tokime T, Akiyama $Y$ : Multinodular and vacuolating neuronal tumor: A case report and literature review. Surg Neurol Int $\mathbf{9}: 63,2018$.

18) Thom M, Liu J, Bongaarts A, Reinten RJ, Paradiso B, Jäger HR, Reeves C, Somani A, An S, Marsdon D, McEvoy A, Miserocchi A, Thorne L, Newman F, Bucur S, Honavar M, Jacques T, Aronica E : Multinodular and vacuolating neuronal tumors in epilepsy : dysplasia or neoplasia? Brain Pathol 28: 155-171, 2018.

19) Vuori K, Kankaanranta L, Häkkinen AM, Gaily E, Valanne L, Granström ML, Joensuu H, Blomstedt G, Paetau A, Lundbom $\mathrm{N}$ : Low-grade gliomas and focal cortical developmental malformations : differentiation with proton MR spectroscopy. Radiology 230 : 703-708, 2004.

20) Yamaguchi M, Komori T, Nakata Y, Yagishita A, Morino M, Isozaki $\mathrm{E}$ : Multinodular and vacuolating neuronal tumor affecting amygdala and hippocampus: A quasi-tumor? Pathol Int $66: 34-41,2016$.

21）山澤恵理香, 大野 誠, 里見介史, 吉田朗彦, 宮北康二, 高橋雅道, 浅野目卓, 里見奈都子, 成田善孝: Multinodular and vacuolating neuronal tumor of the cerebrum の長期 経過と文献的考察。脳外誌 $28: 27-32,2019$.

\section{要}

旨

緩徐な増大が疑われた multinodular and vacuolating neuronal tumor（MVNT）

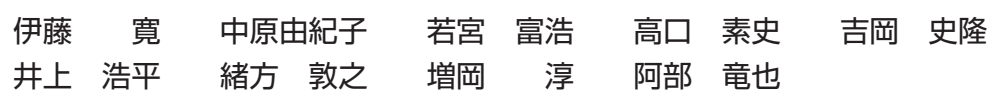

Multinodular and vacuolating neuronal tumor (MVNT) が増大することはまれである. MVNT の 3 例, うち 1 例は緩徐な増大が疑われた例を報告する. MRI では全例, 皮質下に多結節性の T2 延長病 変を示し, 増強効果はなかった. 神経症状はないが, 1 例は緩徐な増大傾向を示していると考えられ, 低悪性度神経膠腫を疑い摘出した. 病理所見では, MVNTに特徵的な多結節性腫瘍が皮質下に進展し, 空胞を有する異型細胞が増殖していた. 免疫組織化学検査ではシナプトフィジン, Olig2 陽性で, 神 経膠腫に特徵的な遺伝子変異はなかった. 緩徐に増大する MVNT と低悪性度神経膠腫を鑑別すること は治療方針決定に重要である. 


\section{重要な鑑別疾患を念頭に置きながら対処すべき病変}

Multinodular and vacuolating neuronal tumor of the cerebrum（MVNT）は，2016 年版の WHO 脳腫瘍分 類の中では「メモ」のようなかたちで記載されてい るが，正式な腫瘍の分類リストには含まれていな い.したがってグレードは記載されておらず，実際 には独立した腫瘍としては認識されるに至っていな い「概念」のようなものと考えるのが適切と思われ る。成人に多く,てんかん発作を契機にみつかる MRI FLAIR 画像高信号域を呈する病変で, ガドリニ ウムによる増強効果は示さない. すなわち low grade glioma（LGG）と診断されやすい特徵をもつ. 画像 所見や病理所見については本論文中で解説されてい るが，BRAFや $I D H 1 / 2$ のような神経膠腫に特徵的 な変異も認めず，多結節状の所見以外には決定的な 特徴がない病変といつてよい. MVNTの診断をされ た症例は十数例程度の報告があるのみであり, これ
藤田医科大学脳神経外科 廣瀬雄一

が neoplasm なのか過誤腫的な病変なのかは明らか になっていない. また文献で報告されている中には 病理診断がされていないものもあり, 他疾患の可能 性が否定できないと思われる.

本症例のように LGG との鑑別が必要な所見を示 す MRI をみることは臨床の場では決してまれでは ないため, 読者の益となる論文である一方, 重大な 疾患ともいえないため, こうした症例報告で情報提 供するのが最も適切なかたちではないかと考える。

ただし, 最も重要な鑑別疾患である LGG は進行 性の腫瘍であり, 近年は可及的最大切除が重視され るため早期に手術される機会も増えている. MVNT と診断される病変をみても経過追跡を疎かにせず, 論文中にあるように MR spectroscopy やPETなどの 画像検査も工夫しながら慎重に対処する必要がある. 